\title{
Pembuatan Aplikasi Berbasis Android sebagai Media Promosi Potensi Wisata di Kawasan Menoreh Samigaluh Kulon Progo
}

\author{
Muhammad Rifqi Al FAuzan ${ }^{\star}$, Sudiartono ${ }^{2}$, Galih Setyawan ${ }^{3}$, Tika Erna Putri ${ }^{4}$, Imam \\ Fakhrurrozi $^{5}$, Ronald Adrian ${ }^{6}$, Atikah Surriani ${ }^{7}$ \\ 1,2,3 Program Studi Metrologi dan Instrumentasi, Departemen Teknik Elektro dan Informatika, \\ Sekolah Vokasi, Universitas Gadjah Mada \\ ${ }_{4}^{4}$ Program Studi Elektronika dan Instrumentasi, Departemen Teknik Elektro dan Informatika, \\ Sekolah Vokasi, Universitas Gadjah Mada \\ ${ }^{5}$ Program Studi Sistem Informasi, Departemen Teknik Elektro dan Informatika, Sekolah \\ Vokasi, Universitas Gadjah Mada \\ ${ }^{6}$ Program Studi Teknologi Jaringan, Departemen Teknik Elektro dan Informatika, Sekolah \\ Vokasi, Universitas Gadjah Mada \\ ${ }^{7}$ Program Studi Teknik Elektro, Departemen Teknik Elektro dan Informatika, Sekolah Vokasi, \\ Universitas Gadjah Mada \\ *Email: alfauzan.rifqi@ugm.ac.id
}

\begin{abstract}
Abstrak
Kegiatan pengabdian kepada masyarakat ini bertujuan untuk membuat media promosi objek wisata yang berada di kawasan Menoreh Kecamatan Samigaluh Kabupaten Kulon Progo. Kawasan Menoreh menyimpan banyak potensi wisata yang masih belum berkembang dengan baik. Tidak banyak informasi yang dapat diperoleh dari internet mengenai wisata di Menoreh. Hal ini dapat dilihat dari jumlah pengunjung yang juga masih rendah. Perlu adanya media promosi yang dapat mempromosikan potensi wisata kawasan Menoreh sehingga akan meningkatkan pula jumlah kunjungan ke kawasan tersebut. Menoreh merupakan kawasan yang sangat potensial bukan hanya karena sumber daya alamnya tetapi juga karena pemerintah melalui Kementerian Pariwisata menetapkan Menoreh sebagai Kawasan Strategis Pariwisata Nasional (KSPN) Borobudur. Ada banyak pilihan media promosi yang dapat digunakan, dalam kegiatan pengabdian kepada masyarakat ini tim pengabdi menggunakan aplikasi berbasis Android (sistem operasi smartphone). Kementerian Komunikasi dan Informatika Republik Indonesia dalam laman resminya memprediksi pada tahun 2018 jumlah pengguna aktif smartphone di Indonesia melebihi 100 juta pengguna. Indonesia akan menjadi negara dengan pengguna aktif smartphone terbesar keempat di dunia setelah Cina, India, dan Amerika Serikat. Dari data tersebut dapat dikatakan promosi menggunakan aplikasi pada smartphone adalah salah satu metode promosi yang paling efektif saat ini.
\end{abstract}

Kata Kunci: kawasan Menoreh, media promosi, potensi wisata

\begin{abstract}
The aim of our community service program is to create promotion media of tourist attraction located in Menoreh, Samigaluh District, Kulon Progo Regency. Menoreh has a lot of not welldeveloped potential tourist attractions. There are not many information that we can obtain in internet about Menoreh attractions. This can be viewed from low number of visitors in Menoreh. Therefore a good promotion media is needed to solve the explained problem. Menoreh is a very potential area not only because of its natural resources but also because the government through the Ministry of Tourism establish Menoreh as a National Tourism Strategic Area (KSPN) Borobudur. There are many choices of promotional media that can be used, in this community service program we use Android-based application. Ministry of Communications and Information Republic of Indonesia in its official website predicts that by 2018 the number of active users of smartphones in Indonesia will exceed of 100 million users. Indonesia will be the country with the
\end{abstract}


fourth largest smartphone active users in the world after China, India and the United States. From the that fact we can said that the promotion with smartphone-based application (by means of Android) is one of the most effective promotional methods today.

Keywords: Menoreh area, promotion media, tourism potential

\section{PENDAHULUAN}

Kulon Progo merupakan salah satu Kabupaten di wilayah Provinsi Daerah Istimewa Yogyakarta. Kabupaten ini berbatasan dengan Kabupaten Sleman dan Kabupaten Bantul di timur, Samudra Hindia di selatan, Kabupaten Purworejo di barat, serta Kabupaten Magelang di utara. Kabupaten Kulon Progo terdiri atas 12 kecamatan, yang dibagi lagi atas 88 desa dan kelurahan, serta 930 Pedukuhan (sebelum otonomi daerah dinamakan Dusun). Pusat pemerintahan di Kecamatan Wates, yang berada sekitar $25 \mathrm{~km}$ sebelah barat daya dari pusat Ibukota Provinsi Yogyakarta. Bagian barat laut wilayah kabupaten ini berupa perbukitan Menoreh, dengan puncaknya puncak Suroloyo (1019 m), di perbatasan dengan Kabupaten Magelang. Kawasan Menoreh ini dijadikan prioritas untuk kegiatan pengabdian Sekolah Vokasi Universitas Gadjah Mada tahun 2017. Salah satu wilayah yang dilewati jalur perbukitan Menoreh adalah Kecamatan Samigaluh. Di kawasan ini pula akan dibangun jalur yang menghubungkan Bandara New Yogyakarta International Airport (NYIA) dengan Candi Borobudur. Oleh karena itu Samigaluh menjadi Kawasan Strategis Pariwisata Nasional (KSPN) Borobudur. Pengabdian ini berfokus pada desa-desa di kawasan Menoreh sesuai hasil rapat koordinasi antara Sekolah Vokasi UGM dan Badan Perencanaan Pembangunan Daerah (BAPPEDA) Kabupaten Kulon Progo.

Kawasan perbukitan Menoreh dikarunia keindahan alam yang sangat potensial untuk tujuan pariwisata, terlebih setelah pemerintah pusat menjadikan kawasan ini sebagai kawasan strategis pariwisata nasional. Beberapa potensi wisata diantaranya kebun teh, kebun kopi beserta kedai-kedai kopi, desa penghasil 104 kakao, pembuatan coklat dan hasil olahan coklat, produk olahan susu kambing PE, wisata durian, dan mungkin masih banyak lagi potensi wisata yang belum termaksimalkan pemanfaatannya. Berdasarkan rapat koordinasi dengan BAPPEDA Kulon Progo diketahui bahwa salah satu kekurangan dari wisata kawasan Menoreh adalah masalah promosi. Oleh karena itu pada pengabdian ini kami mencoba memberikan solusi terhadap masalah tersebut. Dengan promosi yang baik diharapkan akan mengenalkan wisata Menoreh lebih luas lagi dan pada akhirnya akan menaikkan jumlah wisatawan ke wilayah Menoreh.

\section{METODE}

Salah satu desa yang dilewati jalur perbukitan Menoreh adalah Desa Pagerharjo Kecamatan Samigaluh. Desa Pagerharjo ini digunakan sebagai posko pengabdian yang kami lakukan dengan menggandeng Karang Taruna desa tersebut. Namun wilayah pengabdian kami tidak terbatas pada Desa Pagerharjo saja, tetapi mencakup desa-desa lain juga yang ada di kawasan Menoreh. Di desa ini bahkan sudah ada homestay milik penduduk setempat yang dapat menunjang pariwisata kawasan Menoreh. Pada hari Selasa tanggal 21 Maret 2017, kami melakukan survei awal di Desa Pagerharjo dan Kantor Kecamatan Samigaluh untuk memastikan ketepatan tema pengabdian yang dilakukan. Dokumentasi survei ditampilkan pada Gambar 1 dan Gambar 2.

Dibutuhkan solusi konkrit untuk menyelesaikan masalah promosi wisata kawasan Menoreh Kecamatan Samigaluh Kabupaten Kulon Progo. Salah satu solusi yang dapat ditawarkan adalah dengan membuat media promosi pariwisata 

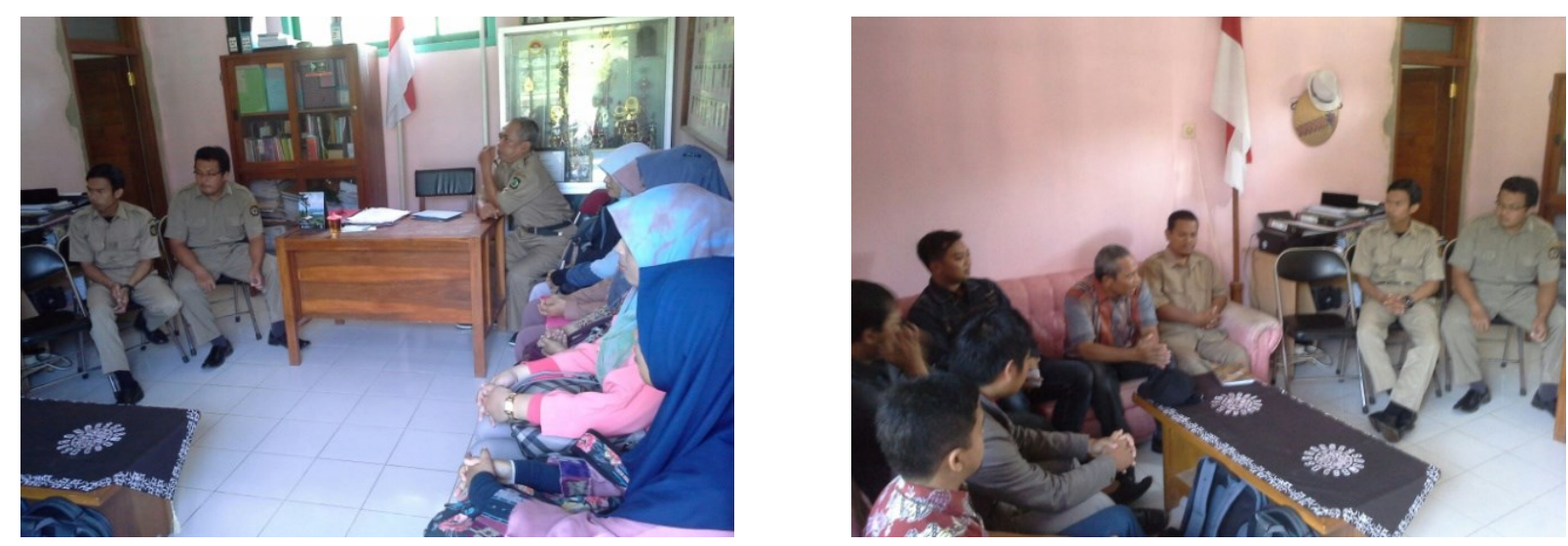

Gambar 1. Rapat koordinasi tim pengabdian dengan perangkat Desa Pagerharjo

terpadu di kawasan Menoreh. Media yang kami gunakan berupa aplikasi pada smartphone yang berisi informasi pariwisata terpadu di kawasan tersebut. Kementerian Komunikasi dan Informatika Republik Indonesia dalam laman resminya memprediksi pada tahun 2018 jumlah pengguna aktif smartphone di Indonesia melebihi 100 juta pengguna. Dengan jumlah sebanyak itu, Indonesia akan menjadi negara dengan pengguna aktif smartphone terbesar keempat di dunia setelah Cina, India, dan Amerika Serikat. Dari data tersebut dapat dikatakan promosi menggunakan aplikasi pada smartphone adalah salah satu metode promosi yang paling efektif saat ini. Aplikasi berbasis Android yang dibuat diberi nama "Wisata Menoreh".

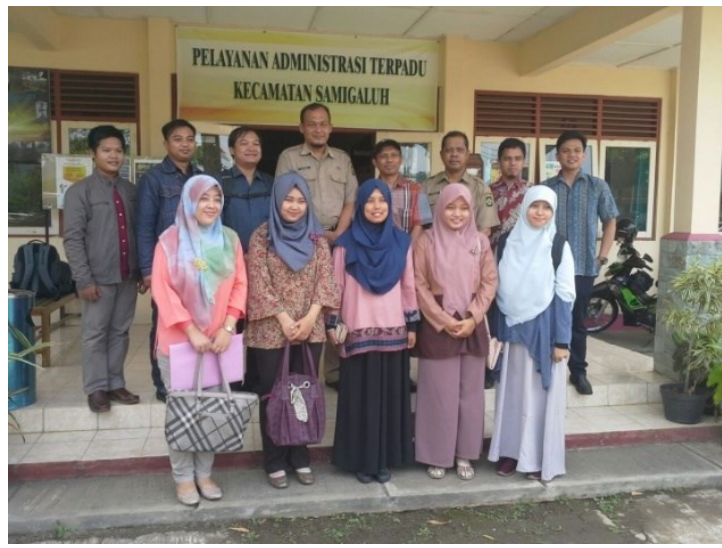

Gambar 2. Tim pengabdian dengan Camat dan Wakil Sekretaris Kecamatan Samigaluh
Pelaksanaan pengabdian dimulai dengan survei awal tim pengabdian ke lokasi pengabdian, proses ini dilakukan pada tanggal 21 Maret 2017. Dari survei tersebut dihasilkan kesepakatan antara tim dan pihak desa maupun kecamatan mengenai tema pengabdian. Tahap berikutnya adalah pendataan atau pemetaan potensi wisata supaya didapatkan data yang akurat dan aktual. Dalam proses ini tim pengabdi melibatkan lembaga Karang Taruna desa setempat secara aktif. Alasannya karena memang pihak yang paling faham mengenai kondisi wilayah pengabdian adalah masyarakat setempat, dalam hal ini diwakilkan Karang Taruna.

Pembuatan dan pengujian aplikasi berbasis Android dibagi menjadi dua tahap, tahap pertama dilaksanakan seusai survei sampai awal Mei. Pada tahap pertama ini dihasilkan aplikasi yang dapat melakukan fungsi-fungsi dasar seperti membuat akun, meng-update berita, menambah objek wisata dan informasinya. Pada tanggal 7 Mei 2017 dilakukan sosialisasi dan pelatihan calon admin bagi aplikasi Wisata Menoreh di balai desa Pagerharjo yang dihadiri perwakilan lima Desa. Lima desa tersebut adalah Pagerharjo, Ngargosari, Gerbosari, Sidoharjo, Purwoharjo. Luaran dari pertemuan tersebut berupa calon admin yang mampu berkontribusi dalam hal menambah atau memperbarui data di aplikasi Wisata Menoreh. Selain itu dalam pertemuan tersebut juga terjadi diskusi yang mengakomodir masukan-masukan dari 
calon admin terkait perbaikan aplikasi yang dibuat. Masukan tersebut dijadikan dasar untuk melakukan pembuatan aplikasi tahap kedua. Tahap ke dua pembuatan aplikasi dilakukan awal Mei sampai akhir Oktober 2017.

\section{HASIL DAN PEMBAHASAN}

Aplikasi berbasis Android yang berisi informasi potensi wisata berbasis wilayah di kawasan perbukitan Menoreh telah berhasil dibuat dan diuji fungsionalitasnya. Aplikasi tersebut bernama "Wisata Menoreh" dan dapat diunduh secara gratis di Google Play. Logo aplikasi Wisata Menoreh berlatar belakang warna hijau dengan huruf "M" di tengah, ditunjukkan pada Gambar 3.

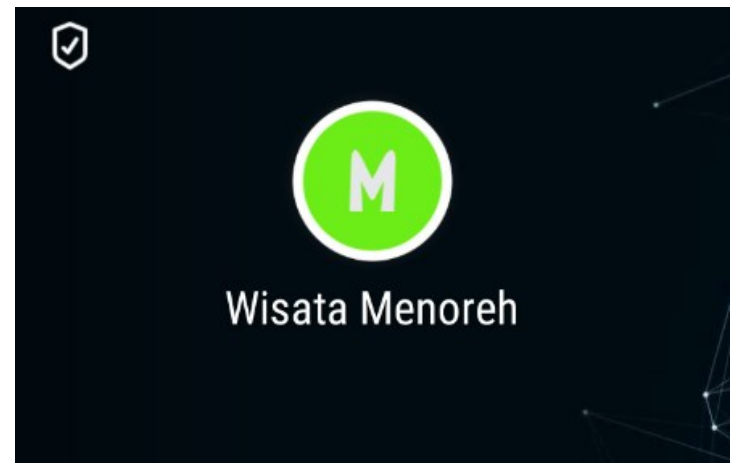

Gambar 3. Screenshoot logo aplikasi Wisata

Menoreh pada layar smartphone.

Warna hijau dipilih karena objek wisata yang ada di kawasan Menoreh berbasis alam dan alam identik dengan warna hijau, sedangkan huruf "M" merupakan inisial dari "Menoreh". Aplikasi Wisata Menoreh berbasis wilayah, artinya data yang ditampilkan dibedakan berdasarkan wilayahnya.

Halaman awal yang akan tertampil ketika aplikasi Wisata Menoreh dibuka ditampilkan pada Gambar 4. Di bagian atas terdapat header bertuliskan "Wisata Menoreh" sebagai nama aplikasi dan menu Log In untuk administrator. Bagian utama halaman awal ini menampilkan nama lima Desa di kawasan Menoreh Kecamatan Samigaluh yaitu Desa Pagerharjo, Ngargosari, Gerbosari, Sidoharjo, dan Purwoharjo. Tiap desa berisi list atau daftar wisata yang ada di desa tersebut. Gambar 5 . 106

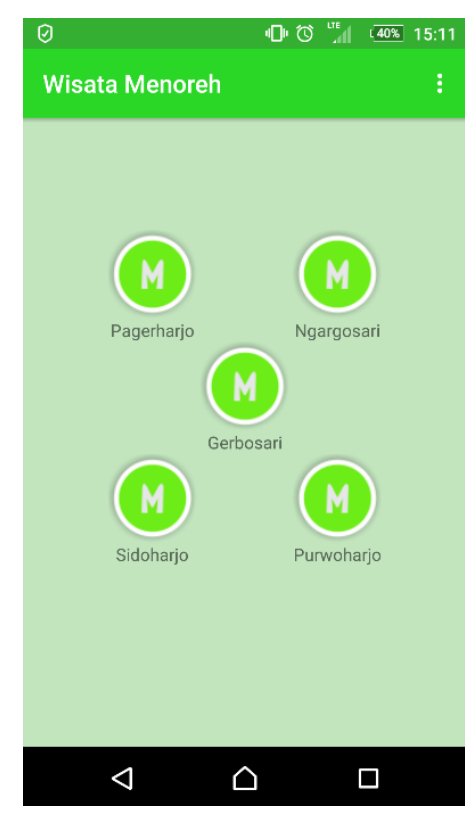

Gambar 4. Tampilan awal aplikasi Wisata Menoreh

menampilkan daftar wisata di desa Pagerharjo. Daftar tersebut dapat ditambah atau dikurangi oleh admin tiap desa, dan tiap admin hanya bertanggung jawab terhadap desanya masing-masing. Tiap daftar wisata menampilkan logo aplikasi, nama objek wisata dan alamatnya.

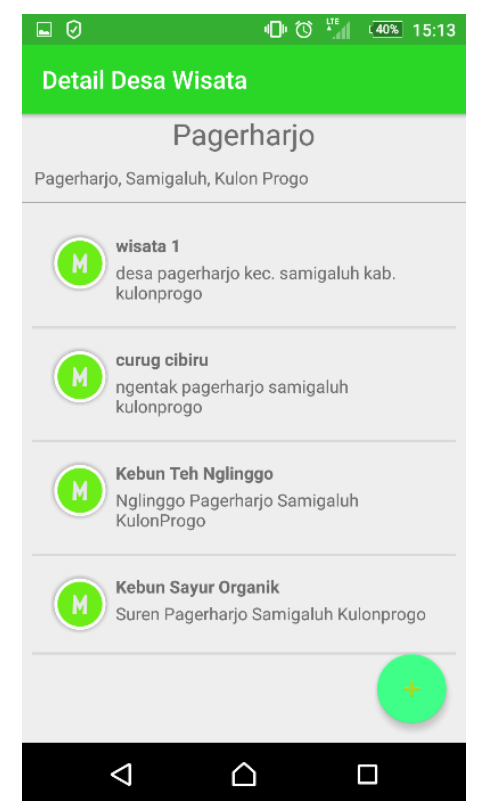

Gambar 5. Contoh daftar wisata yang ada di desa Pagerharjo. 


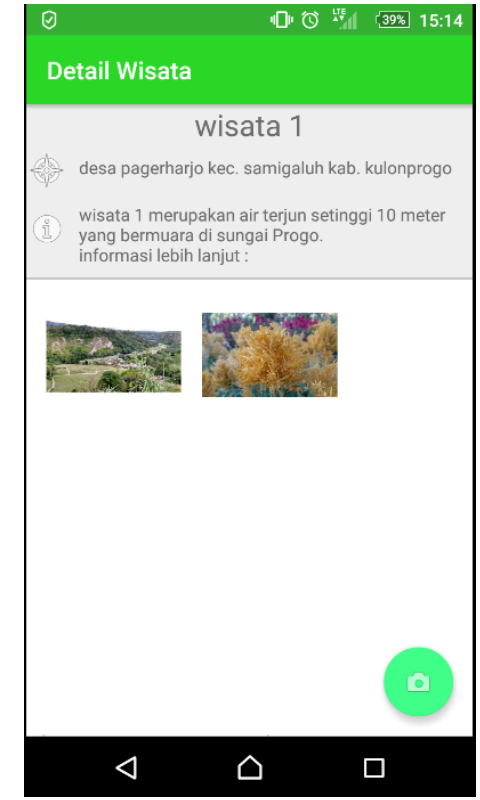

Gambar 6. Tampilan detail wisata

Jika salah satu daftar wisata pada Gambar 5. dibuka, maka akan menghasilkan tampilan detail wisata seperti ditunjukkan pada Gambar 6. Detail wisata menampilkan data nama objek wisata, alamat lengkap, informasi, dan foto-foto yang berkaitan dengan objek wisata tersebut. Data-data tersebut dapat diperbarui oleh admin yang bertanggung jawab terhadap desa yang bersangkutan. Gambar 7. menampilkan halaman akun admin yang berisi data seperti nama desa admin tersebut, nama

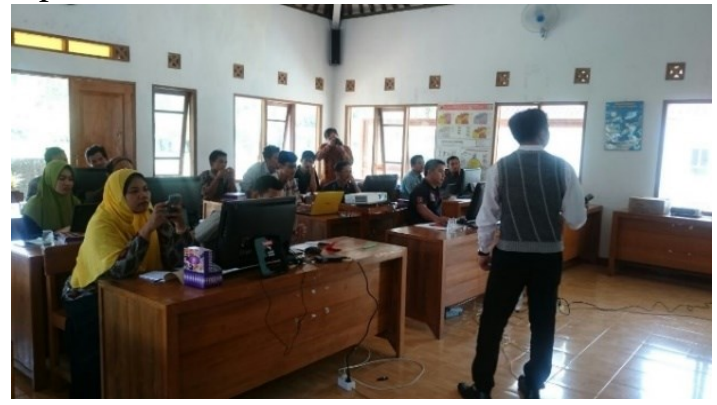

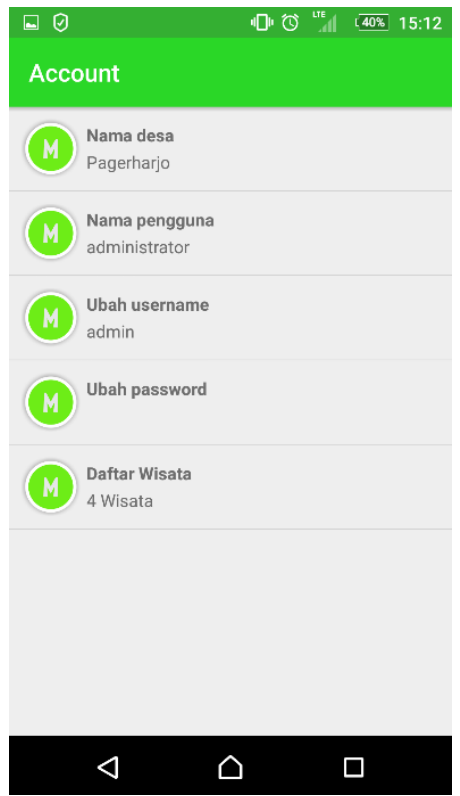

Gambar 7. Halaman akun admin

pengguna (username) admin, fasilitas ubah username, fasilitas ubah password, dan jumlah objek wisata yang terdapat pada desa admin. Pada tanggal 7 Mei 2017 bertempat di Balai Desa Pagerharjo dilakukan pelatihan calon admin aplikasi Wisata Menoreh (lihat Gambar 8.) menggunakan smartphone yang dibawa secara swadaya oleh penduduk lima desa yang menjadi sasaran pengabdian. Pelatihan tersebut dihadiri empat belas peserta calon admin yang berasal dari lima desa.

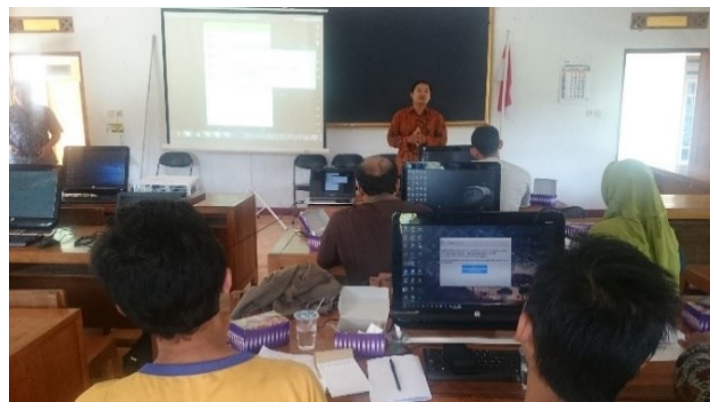

Gambar 8. Dokumentasi pelatihan calon admin aplikasi Wisata Menoreh.

\section{SIMPULAN}

Telah dilaksanakan pengabdian kepada masyarakat yang berlokasi di kawasan perbukitan Menoreh Kecamatan Samigaluh Kabupaten Kulon Progo. Pengabdian ini berfokus pada bidang pariwisata. Perbukitan Menoreh menyimpan banyak potensi wisata yang kurang berkembang, salah satu hal yang diindikasikan menjadi penyebabnya adalah kurangnya promosi terhadap tempat wisata tersebut. Kegiatan pengabdian ini berusaha menjawab masalah tersebut melalui pembuatan media promosi berupa aplikasi berbasis Android yang merupakan sistem 
operasi di smartphone. Media tersebut dipandang akan efektif karena hampir semua orang yang ada diusia produktif memiliki unit smartphone. Aplikasi yang dibuat bernama "Wisata Menoreh" dan dapat diunduh secara gratis di Google Play.

Ada beberapa saran yang dapat diberikan untuk kegiatan pengabdian berikutnya. Pertama, pola komunikasi yang lebih intensif dengan mitra, dalam hal ini Karang Taruna Desa Pagerharjo. Hal ini penting karena aplikasi yang dikembangkan akan bekerja dengan baik jika ada kontribusi dari tim pengabdi Departemen TEDI Sekolah Vokasi UGM dan mitra pengabdian. Saran yang kedua, akan lebih baik jika Karang Taruna dari masing-masing desa dilibatkan semua sebagai mitra pengabdian. Kemudian saran ketiga dari sisi aplikasi yang dibuat perlu adanya perbaikan dari sisi tampilan.

\section{DAFTAR PUSTAKA}

Pemerintah Kabupaten Kulon Progo. (2012). Rencana Tata Ruang Wilayah Kabupaten Kulon Progo 2012-2032. Wates: Sekretaris Daerah Kabupaten Kulon Progo.

Pemerintah Provinsi Daerah Istimewa Yogyakarta. (2010). Rencana Tata Ruang Wilayah Daerah Istimewa Yogyakarta 2009-2029. Yogyakarta: Sekretaris Daerah Provinsi Daerah Istimewa Yogyakarta.

Presiden Republik Indonesia. (2011). Peraturan Pemerintah Republik Indonesia Nomor 50 Tahun 2011 Tentang Rencana Induk Pembangunan Kepariwisataan Nasional Tahun 2010 2025. Jakarta: Kementerian Hukum dan Hak Asasi Manusia Republik Indonesia .

Dadang Rizki Ratman (Deputi Bidang Pengembangan Destinasi dan Investasi Pariwisata). (2016). Pembangunan Destinasi Pariwisata Prioritas 2016 - 2019. Jakarta: Paparan Deputi yang disampaikan pada Rapat Koordinasi Nasional Kementerian Pariwisata.
Maryanto, D.A. (2007). Candi Borobudur. Yogyakarta: Citra Aji Parama.

https://www.kominfo.go.id/content/detail/6 o95/indonesia-raksasa-teknologidigital-asia/o/sorotan_media (diakses pada 20 Maret 2017).

Nazruddin Safaat. (2014). Android Pemrograman Aplikasi Mobile Smartphone. Bandung: Penerbit Informatika.

Alfa Satyaputra dan Eva M. Aritonang. (2016). Let's Build Your Android Apps with Android Studio. Jakarta: Elex media Komputindo. 